Article

\title{
Ordered mesoporous Sn-SBA-15 as support for Pt catalyst with enhanced performance in propane dehydrogenation
}

\author{
Bing $\mathrm{Li}^{\mathrm{a}}$, Zhenxin $\mathrm{Xu}{ }^{\mathrm{b}}$, Wei Chu a, Shizhong Luo ${ }^{\mathrm{a}, *}$, Fangli Jing a,\# \\ a School of Chemical Engineering, Sichuan University, Chengdu 610065, Sichuan, China \\ ${ }^{\mathrm{b}}$ Institut de Chimie et Procédés pour l'Energie, l'Environnement et la Santé (ICPEES), UMR 7515 CNRS-Université de Strasbourg (UdS), 25, rue Becquerel, \\ 67087 Strasbourg Cedex 08, France
}

\section{A R T I C L E I N F O}

\section{Article history:}

Received 11 January 2017

Accepted 3 March 2017

Published 5 April 2017

\section{Keywords:}

Propane dehydrogenation

One-pot hydrothermal synthesis

Sn-incorporated SBA-15

Pt-based catalyst

Structure activity relationship

\begin{abstract}
A B S T R A C T
A series of Sn-incorporated SBA-15 materials with high specific surface areas and highly ordered mesoporous structures were synthesized by a facile one-pot method and used as catalyst supports. A reference sample was also prepared using a conventional impregnation method. The catalysts were characterized using various methods, and their activities in propane dehydrogenation were investigated. The incorporation of Sn into the SBA-15 matrix led to strong interactions between $\mathrm{Sn}$ species and the support, and these helped to maintain the oxidation states of Sn species during the reaction. Substitution with Sn changed the interfacial properties of the Pt species and improved the function and effect of the Sn promoter. The catalytic activities and stabilities of the Pt catalysts supported on Sn-incorporated SBA-15 were better than those of the impregnated sample. However, the catalytic performance deteriorated when an excessive amount of Sn was introduced and the interactions among Pt, Sn species, and the support became weaker. The Pt/0.5Sn-SBA-15 catalyst gave the best propene selectivity, i.e., $98.5 \%$, with a corresponding propane conversion of about $43.8 \%$.
\end{abstract}

(C) 2017, Dalian Institute of Chemical Physics, Chinese Academy of Sciences. Published by Elsevier B.V. All rights reserved.

\section{Introduction}

Propane is an important raw material in the production of various chemicals and of great practical value in various reactions such as polypropylene, propylene oxide, and acrylonitrile syntheses. Steam cracking and fluidized catalytic cracking of naphtha are common processes for the commercial synthesis of propene [1-3]. Recently, propane dehydrogenation has been widely investigated as an effective approach to propene production because of the continuing decrease in fossil oil resources and the increasing market for propene [4-6]. Low-cost saturated hydrocarbons can be converted to value-added ole- fins by propane dehydrogenation, and this route is economically competitive [7]. Propane dehydrogenation is a highly endothermic and equilibrium-limited reaction, therefore a high temperature is needed to obtain a satisfactory yield of propene [8]. However, problems such as hydrocarbon cracking and coke formation arise with increasing reaction temperature, and these lead to decreases in the activity and stability of the catalyst [9].

Currently, catalysts based on chromium oxide or Pt are the main catalysts being investigated for propane dehydrogenation. Cr-based catalysts have been extensively researched, but their practical applications are limited because of severe pollu-

\footnotetext{
* Corresponding author. Tel: +86-28-85403836; Fax: +86-28-85461108; E-mail: luosz@scu.edu.cn

\# Corresponding author. Tel: +86-28-85403836; Fax: +86-28-85461108; E-mail: fangli.jing@scu.edu.cn

This work was supported by the Science \& Technology Support Plan Projects of Sichuan Province (2016GZ0371) and National Natural Science Foundation of China (NNSFC, 21476145, 21506111).

DOI: 10.1016/S1872-2067(17)62805-5 | http://www.sciencedirect.com/science/journal/18722067 | Chin. J. Catal., Vol. 38, No. 4, April 2017
} 
tion by chromium $[10,11]$. Pt-based catalysts show good initial activities in propane dehydrogenation; this is because Pt activates $\mathrm{C}-\mathrm{H}$ bonds without promoting $\mathrm{C}-\mathrm{C}$ cleavage $[12,13]$. However, undesired thermal cracking and coke deposition rapidly deactivate these catalysts [14]. The development of efficient catalysts with high selectivities for propene and excellent anti-coking abilities is therefore important.

Considerable research has been devoted to developing methods such as promoter addition for improving the catalytic performances of Pt-based catalysts for propane dehydrogenation. The introduction of Sn promoters into a Pt-based catalytic system effectively improves the catalytic activity, resistance to coke formation, and operating lifetime of the catalyst $[13,14]$. The Sn promoter modifies the properties of Pt-based catalysts via geometric and electronic effects $[15,16]$. A number of studies have shown that the presence of $\mathrm{Sn}$ reduces the Pt particle size and also alters the electronic environment of $\mathrm{Pt}$ as a result of migration of positive charges from $\mathrm{Sn}^{n+}$ or Pt-Sn alloys $[17,18]$. It has been proposed that an oxidized $S n$ promoter can greatly improve the catalytic performance, but metallic Sn acts as a poison [19]. The preparation method, support properties, and metal loading clearly affect the performances of Pt-Sn catalysts [20]. Supports with large surface areas and well-distributed pore sizes to improve dispersion of the metal particles are preferable [21]. The use of SBA-15 as a support for Pt-Sn catalysts for propane dehydrogenation may therefore be an excellent choice. The mesoporous structure of SBA-15 enables it to confine and stabilize Pt nanoparticles and prevent particle agglomeration, making it a good host [22].

The reported methods for introduction of a Sn promoter almost all involve traditional post-synthesis procedures $[23,24]$. Such processes often give uneven distributions of $\mathrm{Sn}$ species, and block the pores and channels, leading to a decrease in the surface area and loss of efficiency of the Sn promoter [25]. This paper describes the preparation of homogeneous Sn-SBA-15 composites using a facile one-pot hydrothermal method. In contrast to traditional methods, the direct synthesis of Sn-SBA-15 can prevent pore clogging and achieve a good distribution of Sn species in the silica matrix. Sn/SBA-15 synthesized using a conventional impregnation method was used as a reference sample. These Sn-modified materials were used as supports for Pt-based catalysts and tested in propane dehydrogenation. The differences among the samples in terms of structure-activity relationships were identified and discussed. The conclusions were used to explain the specific catalytic properties.

\section{Experimental}

\subsection{Catalyst preparation}

The Sn-modified mesoporous SBA-15 material was prepared using a one-pot hydrothermal method. In a typical procedure, a triblock copolymer ( $2 \mathrm{~g}, \mathrm{P} 123, \mathrm{EO}_{20} \mathrm{PO}_{70} \mathrm{EO}_{20}$, Aldrich) was dissolved in $\mathrm{HCl}(60 \mathrm{~mL} ; 2 \mathrm{~mol} / \mathrm{L})$ and deionized water (15 $\mathrm{mL}$ ). A calculated amount of $\mathrm{SnCl}_{2} \cdot 2 \mathrm{H}_{2} \mathrm{O}$ (Aldrich) was added. The mixture was stirred at $40{ }^{\circ} \mathrm{C}$ for $3 \mathrm{~h}$. Tetraethyl orthosili- cate $(4.25 \mathrm{~g}, 98 \%$ ) was added dropwise and the mixture was stirred for $24 \mathrm{~h}$. The resulting suspension was crystallized in a Teflon-lined autoclave at $100{ }^{\circ} \mathrm{C}$ for $24 \mathrm{~h}$. The mixture was filtered, and the residue was washed and dried at $80^{\circ} \mathrm{C}$ for $12 \mathrm{~h}$, and calcined in air at $550{ }^{\circ} \mathrm{C}$ for $6 \mathrm{~h}$. The obtained samples were denoted by $x$ Sn-SBA-15 (nominal Sn mass fraction $x$ wt $\%=0$, $0.5,1$, and $2 \mathrm{wt} \%$ ). Another sample was synthesized using an incipient wetness impregnation (IM) procedure and denoted by $x$ Sn/SBA-15-IM.

The Pt-based catalysts were prepared using an incipient wetness impregnation method. The support powder was impregnated with a $\mathrm{H}_{2} \mathrm{PtCl}_{6} \cdot 6 \mathrm{H}_{2} \mathrm{O}$ precursor dissolved in deionized water. After sonication for $30 \mathrm{~min}$, the mixture was rested for $12 \mathrm{~h}$. The solution was dried at $60^{\circ} \mathrm{C}$ for $12 \mathrm{~h}$ and calcined in air at $500{ }^{\circ} \mathrm{C}$ for $4 \mathrm{~h}$. The nominal Pt content of these catalysts was $1 \mathrm{wt} \%$.

\subsection{Catalyst characterization}

$\mathrm{N}_{2}$ adsorption-desorption isotherms were recorded at -196 ${ }^{\circ} \mathrm{C}$ using an automated surface area and pore size analyzer (Quadrasorb SI). Before each measurement, the samples were outgassed for $3 \mathrm{~h}$ under vacuum at $300{ }^{\circ} \mathrm{C}$. X-ray diffraction (XRD) patterns were recorded at $2 \theta=0.5^{\circ}-10^{\circ}$ using an Empyrean diffractometer with $\mathrm{Cu} K_{\alpha}(45 \mathrm{kV}, 50 \mathrm{~mA})$ radiation.

Fourier-transform infrared (FT-IR) spectra were recorded ate room temperature using a Bruker Tensor 27 FT spectrometer. The spectra were recorded in the range $4000-400 \mathrm{~cm}^{-1}$ and $\mathrm{KBr}$ was used as the background. Ultraviolet-visible (UV-vis) diffuse reflectance spectra were recorded using a Shimadzu UV-vis-near IR spectrophotometer (UV-3600). The NMR spectroscopic studies for Sn-SBA-15 samples were carried out on a Bruker Avance III 500 spectrometer.

X-ray photoelectron spectroscopy (XPS) was performed using an XSAM800 spectrometer with an Al $K_{\alpha}(h v=1486.6 \mathrm{eV})$ $\mathrm{X}$-ray source; the $\mathrm{C} 1 \mathrm{~s}$ binding energy at $284.6 \mathrm{eV}$ was used as an internal standard.

The Sn loadings on the samples were determined using inductively coupled plasma atomic emission spectroscopy (TJA IRIS Advantage spectrometer).

Temperature-programmed $\mathrm{H}_{2}$ desorption ( $\mathrm{H}_{2}$-TPD) was performed using a Quantachrome Autosorb-1 instrument equipped with a thermal conductivity detector. The catalyst (100 mg) was reduced in situ at $500{ }^{\circ} \mathrm{C}$ for $1 \mathrm{~h}$ under a $10 \% \mathrm{H}_{2}-90 \% \mathrm{~N}_{2}$ mixture at a flow rate of $30 \mathrm{~mL} / \mathrm{min}$. The catalyst was cooled to $30{ }^{\circ} \mathrm{C}$ after saturation with $\mathrm{H}_{2}$ and then purged for $3 \mathrm{~h}$ to remove $\mathrm{H}_{2}$ in the gas phase. The TPD profiles were recorded from 30 to $800{ }^{\circ} \mathrm{C}$ at a ramping rate of 10 ${ }^{\circ} \mathrm{C} / \mathrm{min}$.

Scanning electron microscopy (SEM) was performed using a JEOL JSM-7500F instrument at an applied voltage of $10 \mathrm{kV}$. Transmission electron microscopy (TEM) was performed using a JEOL JEM 2010 electron microscope operated at $120.0 \mathrm{kV}$. The samples were suspended in ethanol by ultrasonication. Drops of the suspension were dispersed on a copper grid.

Thermogravimetric analysis (TGA) was performed using a Q500 thermogravimetric analyzer. The samples were heated 
from room temperature to $750{ }^{\circ} \mathrm{C}$ in air at a heating rate of 10 ${ }^{\circ} \mathrm{C} / \mathrm{min}$.

\subsection{Catalytic performance}

The catalytic performances of the samples were investigated using a quartz-tube fixed-bed reactor. The catalyst $(0.2 \mathrm{~g})$ was placed at the center of the reactor and reduced in situ at $500{ }^{\circ} \mathrm{C}$ for $1 \mathrm{~h}$ under $\mathrm{H}_{2}$. The reaction conditions were $580{ }^{\circ} \mathrm{C}$, atmospheric pressure, propane:Ar $=7: 3$ (molar ratio), and propane weight hourly space velocity (WHSV) $=8.25 \mathrm{~h}^{-1}$. The products were analyzed on-line using a GC-3000B gas chromatography system equipped with a thermal conductivity detector. The propane conversion $(X)$ and the selectivity for propene $(S)$ were defined as follows:

$$
X=\left(F_{\mathrm{C} 3 \mathrm{H} 8, \text { in }}-F_{\mathrm{C} 3 \mathrm{H} 8, \mathrm{out}}\right) / F_{\mathrm{C} 3 \mathrm{H} 8, \mathrm{in}} \times 100 \%
$$

$$
S=\left(F_{\mathrm{C} 3 \mathrm{H} 6, \text { out }}-F_{\mathrm{C} 3 \mathrm{H} 6 \text {,in }}\right) /\left(F_{\mathrm{C} 3 \mathrm{H} 8, \mathrm{in}}-F_{\mathrm{C} 3 \mathrm{H} 8, \mathrm{out}}\right) \times 100 \%
$$

where $F_{i, \text { in/out }}$ is the flow rate of each component in the feed or effluent.

\section{Results and discussion}

\subsection{Catalyst characterization}

The effects of Sn addition on the pore structure of SBA-15 were determined based on $\mathrm{N}_{2}$ adsorption-desorption; the results are shown in Fig. 1. The isotherm of SBA-15 was type IV with an $\mathrm{H} 1$ hysteresis loop, indicating cylindrical channels, according to the International Union of Pure and Applied Chemistry classification [26,27]. The shapes of the $x$ Sn-SBA-15 isotherms were similar to that of SBA-15, indicating that the characteristics of the mesoporous material were retained. The pore size distributions were homogeneous and concentrated in the range $5-8 \mathrm{~nm}$. The textural properties are summarized in Table 1. The total surface areas and total pore volumes of the samples increased with increasing Sn content in SBA-15. This suggests that SBA-15 contained a considerable amount of micropores, which were generated around the corona of the silica wall [28]. The decrease in the micropore volume was principally caused by micropore plugging by the incorporated Sn.

Fig. 2 shows the low-angle XRD patterns of SBA-15 and Sn-modified SBA-15 samples. The patterns for $x$ Sn-SBA-15 were similar to that of SBA-15, with three distinct peaks at $2 \theta=$ $0.94^{\circ}, 1.53^{\circ}$, and $1.78^{\circ}$, corresponding to the (100), (110), and (200) reflections, respectively [29]. This shows that the characteristic hexagonal structure was retained in the $x$ Sn-SBA-15 samples. The unit cell parameters $\left(a_{0}\right)$ calculated from the $d_{100}$ spacings are listed in Table 1 . The unit cell parameter $a_{0}$ of SBA-15 was $10.6 \mathrm{~nm}$, and those of the Sn-modified SBA-15 samples were $10.7-10.9 \mathrm{~nm}$.
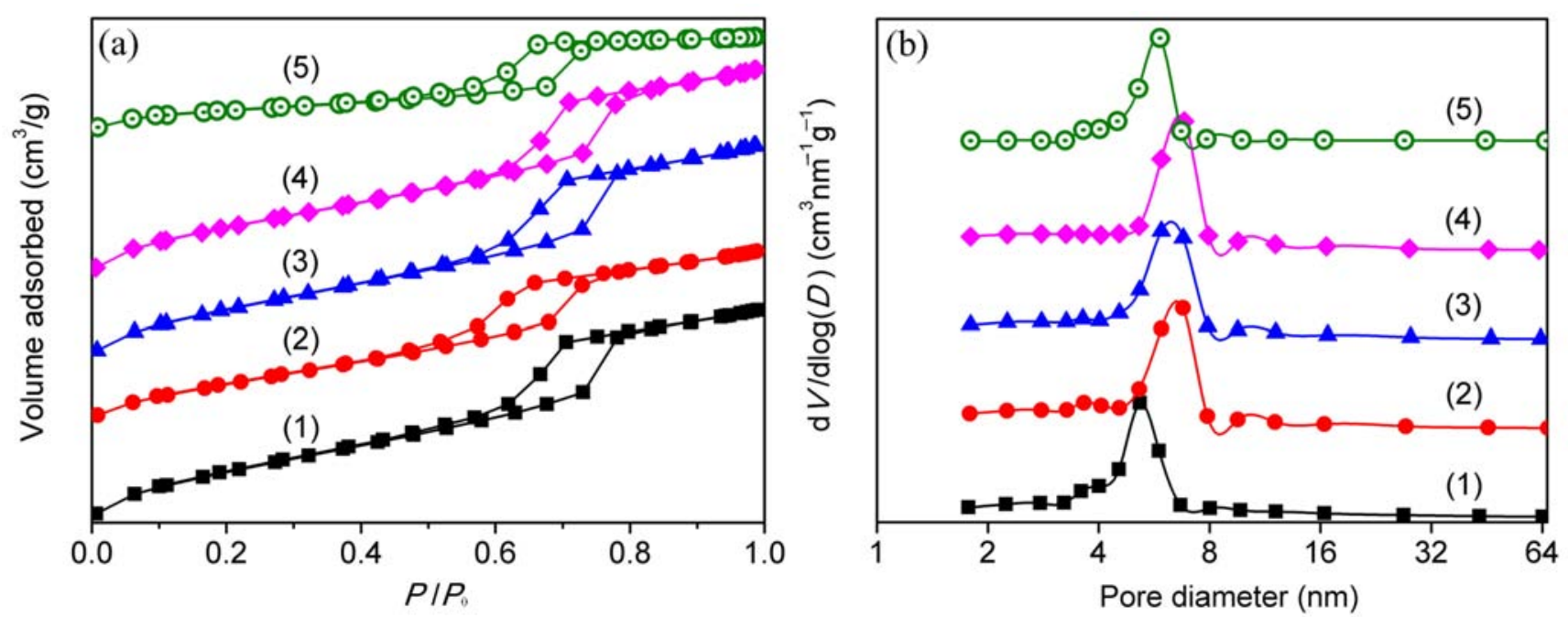

Fig. 1. (a) $\mathrm{N}_{2}$ adsorption-desorption isotherms and (b) pore size distributions of (1) SBA-15; (2) 0.5Sn-SBA-15; (3) 1Sn-SBA-15; (4) 2Sn-SBA-15; (5) 0.5Sn/SBA-15-IM.

Table 1

\begin{tabular}{|c|c|c|c|c|c|c|c|}
\hline Sample & $\begin{array}{l}\text { Total surface area } \\
\left(\mathrm{m}^{2} / \mathrm{g}\right)\end{array}$ & $\begin{array}{l}\text { Total pore volume } \\
\left(\mathrm{cm}^{3} / \mathrm{g}\right)\end{array}$ & $\begin{array}{l}\text { Pore size } \\
\left(d_{\mathrm{P}} / \mathrm{nm}\right)\end{array}$ & $\begin{array}{l}\text { Micropore volume } \\
\left(\mathrm{cm}^{3} / \mathrm{g}\right)\end{array}$ & $\begin{array}{l}d \text {-Spacing } \\
\left(d_{100} / \mathrm{nm}\right)\end{array}$ & $\begin{array}{l}\text { Unit cell parameter }^{\mathrm{a}} \\
\left(a_{0} / \mathrm{nm}\right)\end{array}$ & $\begin{array}{c}\text { Sn loading } \\
\text { (wt } \%)\end{array}$ \\
\hline SBA-15 & 918.4 & 1.33 & 5.4 & 0.18 & 9.2 & 10.6 & - \\
\hline $0.5 \mathrm{Sn}-\mathrm{SBA}-15$ & 893.6 & 1.29 & 5.4 & 0.12 & 9.3 & 10.7 & 0.39 \\
\hline 1Sn-SBA-15 & 884.9 & 1.30 & 5.3 & 0.11 & 9.3 & 10.7 & 0.80 \\
\hline 2Sn-SBA-15 & 851.8 & 1.27 & 5.3 & 0.10 & 9.4 & 10.9 & 1.58 \\
\hline $0.5 \mathrm{Sn} / \mathrm{SBA}-15-\mathrm{IM}$ & 773.3 & 1.26 & 5.2 & 0.12 & 9.3 & 10.7 & 0.43 \\
\hline
\end{tabular}

Textural properties of SBA-15 and Sn-modified SBA-15 materials.

${ }^{\mathrm{a}} a_{0}=2 d_{100} / \sqrt{3}$. 


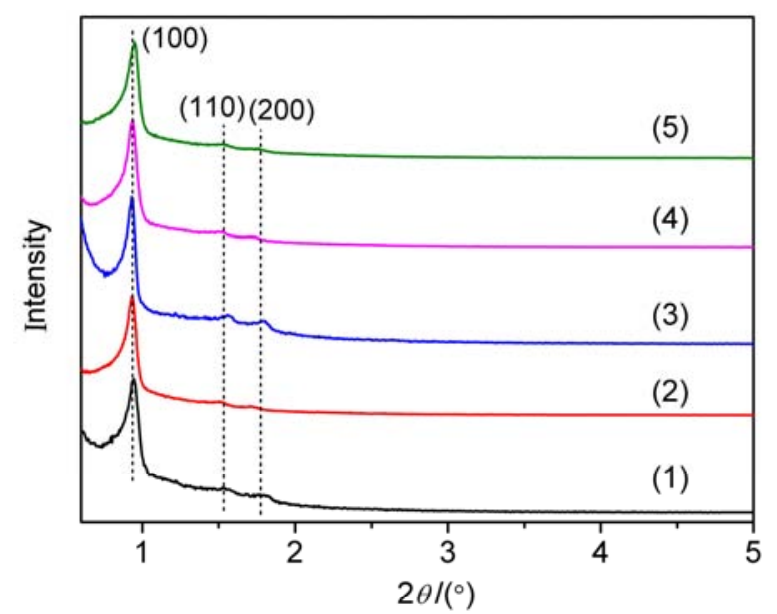

Fig. 2. Low-angle XRD patterns of SBA-15 and Sn-modified SBA-15 materials. (1) SBA-15; (2) 0.5Sn-SBA-15; (3) 1Sn-SBA-15; (4) 2Sn-SBA-15; (5) 0.5Sn/SBA-15-IM.

The $x$ Sn-SBA-15 structures were investigated using FT-IR spectroscopy; the spectra are shown in Fig. 3. The absorption bands at about 463,800 , and $1079 \mathrm{~cm}^{-1}$ are ascribed to the bending, symmetric stretching, and asymmetric stretching vibrations, respectively, of Si-O-Si bonds [30]. The band at 960 $\mathrm{cm}^{-1}$ corresponds to the $\mathrm{Si}-\mathrm{O}-\mathrm{H}$ vibration mode [31]. The intensity of the peak at $960 \mathrm{~cm}^{-1}$ decreased with increasing $\mathrm{Sn}$ content, indicating a decrease in the number of silanol groups in Sn-SBA-15 [32,33]. This can be ascribed to the formation of $\mathrm{Si}-\mathrm{O}-\mathrm{Sn}$ bonds and/or the substitution of tetrahedral Si by $\mathrm{Sn}$ in SBA-15.

UV-vis diffuse reflectance spectroscopy was used to determine the chemical nature and coordination states of the Sn species in SBA-15; the spectra are shown in Fig. 4. The spectra of the calcined $x \mathrm{Sn}$-SBA-15 samples show two absorption bands at 216 and $270 \mathrm{~nm}$. The band at $216 \mathrm{~nm}$ arises from ligand-to-metal charge transfer of $\mathrm{O}-\mathrm{Sn}$ in a tetrahedral $\left(\mathrm{T}_{\mathrm{d}}\right)$ coordination environment, and the band gap transitions of $\mathrm{Sn}^{4+}$

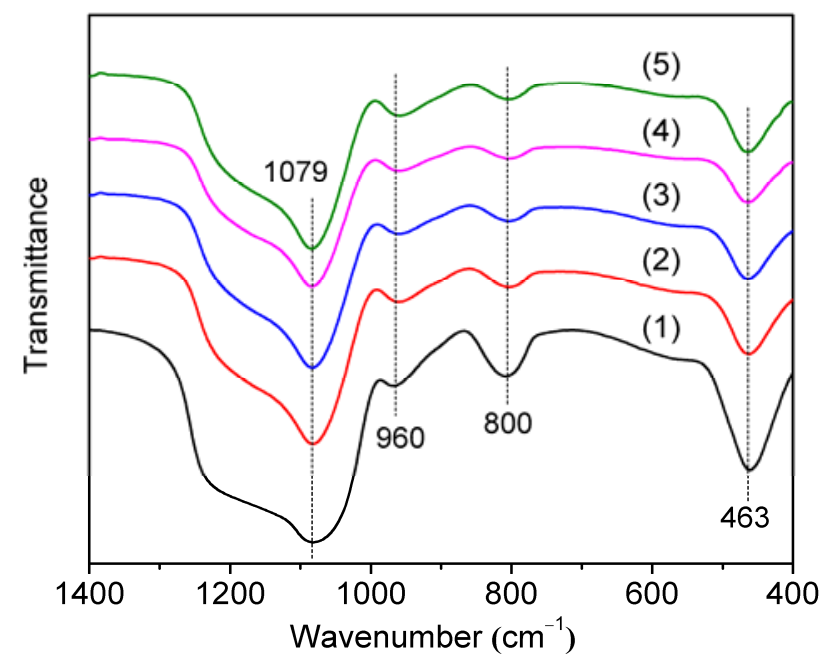

Fig. 3. FT-IR spectra of various samples. (1) SBA-15; (2) 0.5Sn-SBA-15; (3) 1Sn-SBA-15; (4) 2Sn-SBA-15; (5) 0.5Sn/SBA-15-IM.

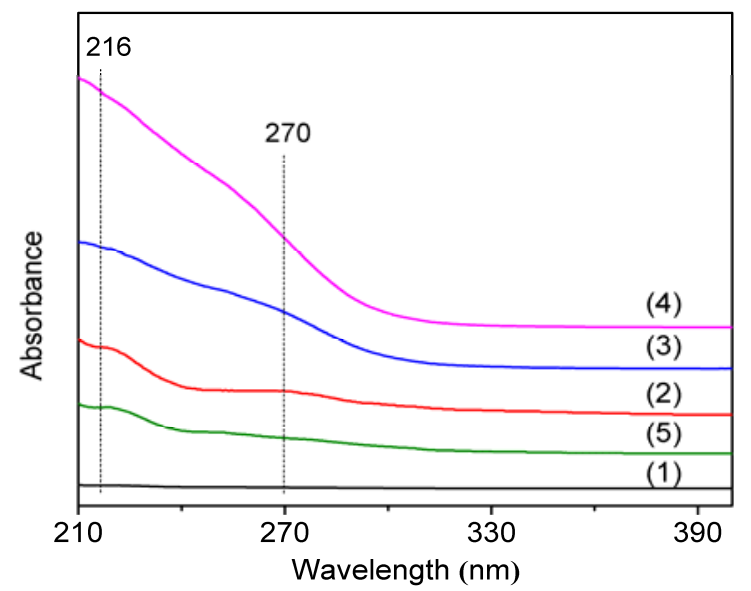

Fig. 4. UV-vis diffuse reflectance spectra of calcined samples. (1) SBA-15; (2) 0.5Sn-SBA-15; (3) 1Sn-SBA-15; (4) 2Sn-SBA-15; (5) $0.5 \mathrm{Sn} / \mathrm{SBA}-15-\mathrm{IM}$.

ions in an octahedral $\left(\mathrm{O}_{h}\right)$ environment are responsible for the band at $270 \mathrm{~nm}[34,35]$. The absorption peak below $250 \mathrm{~nm}$ in the UV-vis spectra shows incorporation of metal atoms into the framework [14]. Fig. 4 shows that the intensity of the absorption band below $250 \mathrm{~nm}$ in the spectrum of $0.5 \mathrm{Sn} / \mathrm{SBA}-15$-IM is much weaker than that of the corresponding band in the $0.5 \mathrm{Sn}-\mathrm{SBA}-15$ spectrum. The intensity of the absorbance at around $216 \mathrm{~nm}$ increased with increasing Sn content, suggesting that a substantial fraction of $\mathrm{Sn}\left(\mathrm{T}_{\mathrm{d}}\right)$ was dispersed in the silica matrix. These results confirm the incorporation of $\mathrm{Sn}$ species into the silica framework of SBA-15, in agreement with reported results [36,37].

Fig. 5 shows ${ }^{29} \mathrm{Si}$ magical-angle spinning nuclear magnetic resonance (MAS NMR) spectra of the calcined Sn-SBA-15 samples. All the spectra show two lines, with chemical shifts at -110.8 and $-101.5 \mathrm{ppm}$, which can be ascribed to Sn substitution in $\mathrm{Si}(\mathrm{OSi})_{4}\left(\mathrm{Q}_{4}\right)$ and $\mathrm{Si}(\mathrm{OH})(\mathrm{OSi})_{3}\left(\mathrm{Q}_{3}\right)$ environments, respectively [38]. The $\mathrm{Q}_{4} / \mathrm{Q}_{3}$ ratio increased with increasing $\mathrm{Sn}$ content, indicating $\mathrm{Sn}$ incorporation adjacent to the $\mathrm{SiO}_{4}$ tetra-

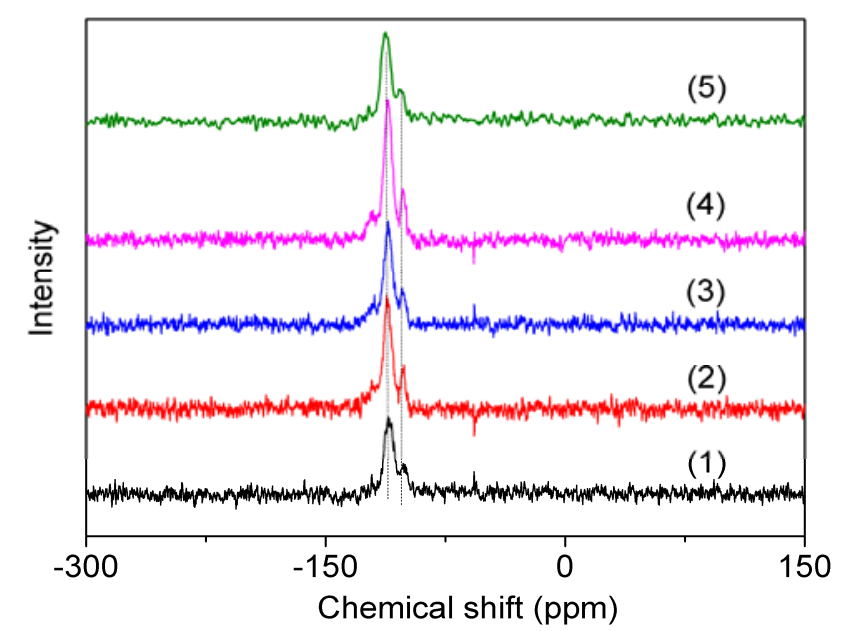

Fig. 5. ${ }^{29} \mathrm{Si}$ MAS NMR spectra of calcined samples. (1) SBA-15; (2) 0.5Sn-SBA-15; (3) 1Sn-SBA-15; (4) 2Sn-SBA-15; (5) 0.5Sn/SBA-15-IM. 


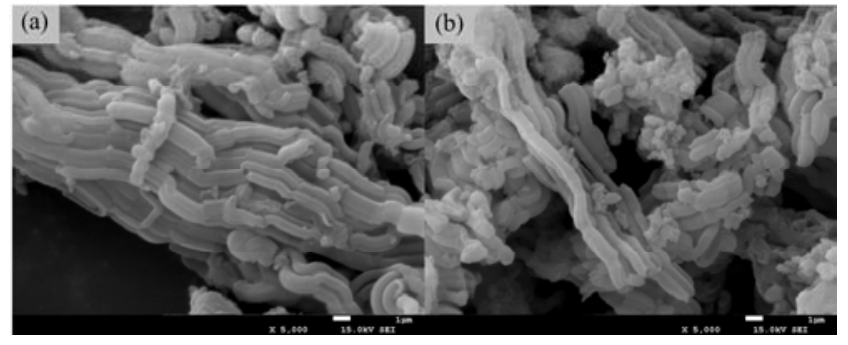

Fig. 6. SEM images of (a) SBA-15 and (b) 2Sn-SBA-15.

hedral units [39]. The $\mathrm{Q}_{4} / \mathrm{Q}_{3}$ ratio for the 0.5Sn/SBA-15-IM sample was less than that for $0.5 \mathrm{Sn}-\mathrm{SBA}-15$, indicating condensation between silanol groups during the formation of Sn-SBA-15. These results show that the $\mathrm{Sn}^{4+}$ species were tightly integrated into the mesoporous silica walls.

The morphologies of SBA-15 and 2Sn-SBA-15 were examined using SEM. Fig. 6 shows that SBA-15 and 2Sn-SBA-15 all consisted of many rope-like domains with uniform relative sizes of $\sim 1 \mu \mathrm{m}$. The images in Fig. 6 are similar to those published by Zhao et al. [40]. The similar surface profiles of SBA-15 and 2Sn-SBA-15 indicate that the introduction of Sn did not affect the morphology.

The wide-angle XRD patterns of these materials are shown in Fig. 7. A broad peak at $2 \theta=23.5^{\circ}$ corresponding to amorphous silica was present in all the patterns. The reflections at $2 \theta=39.8^{\circ}, 46.2^{\circ}, 67.4^{\circ}, 81.4^{\circ}$, and $85.7^{\circ}$ are attributed to the (111), (200), (220), (311), and (222) planes, respectively, of cubic Pt metal [41]. A reflection at $2 \theta=51.7^{\circ}$ from $\mathrm{SnO}_{2}$ was observed for the samples with more than (1-2) wt\% incorporated $S n$ and the $0.5 \mathrm{wt} \%$ impregnated sample [42]. This diffraction peak is probably absent from the Pt/0.5Sn-SBA-15 catalyst pattern because of good dispersion of Sn species or the formation of amorphous $\mathrm{SnO}_{x}$ phases. These results indicate that direct synthesis of Sn-modified SBA-15 gave a better distribution of Sn species.

Fig. 8 shows TEM images of the reduced catalysts. The im-

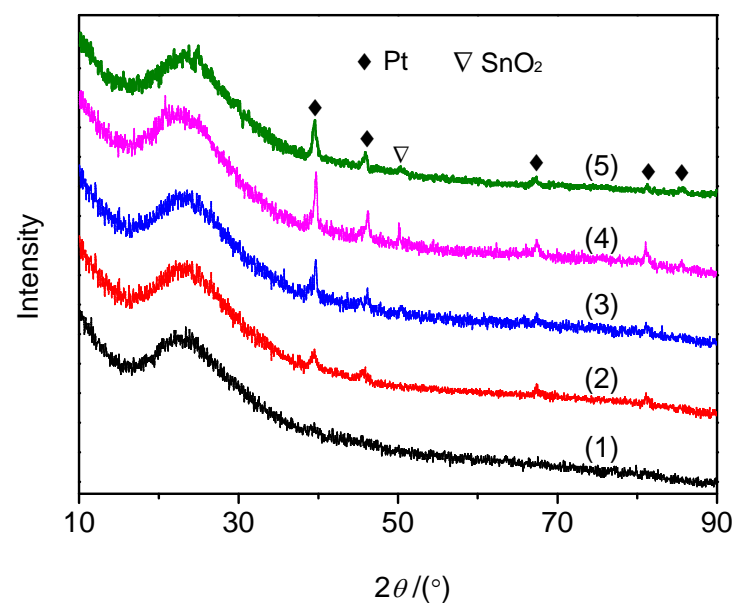

Fig. 7. Wide-angle XRD patterns of SBA-15 and reduced catalysts. (1) SBA-15; (2) Pt/0.5Sn-SBA-15; (3) Pt/1Sn-SBA-15; (4) Pt/2Sn-SBA-15; (5) Pt/0.5Sn/SBA-15-IM.

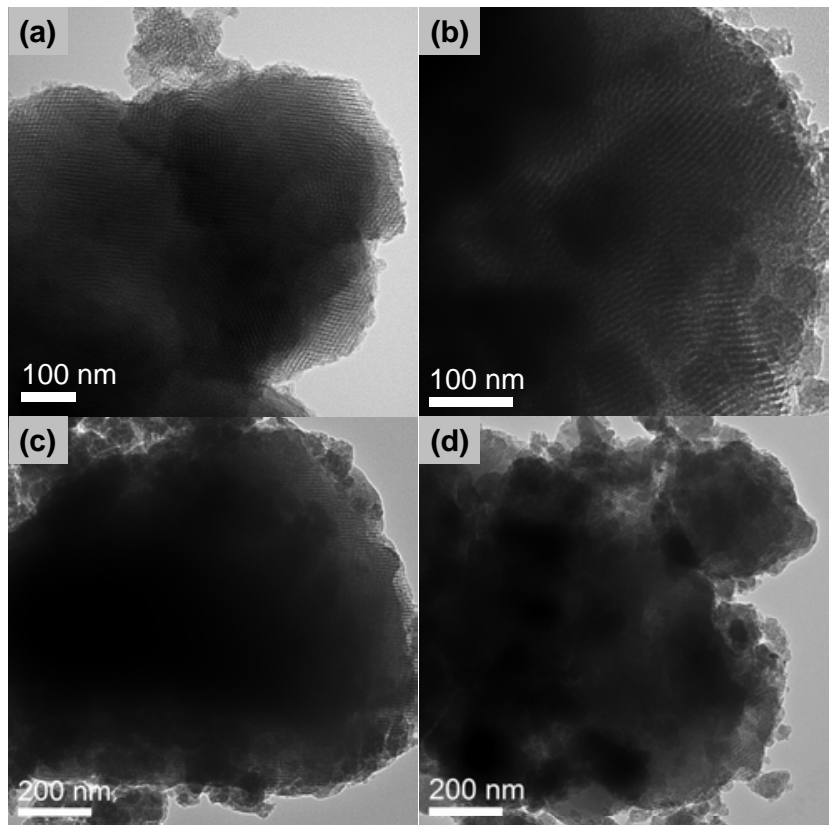

Fig. 8. TEM images of reduced catalysts. (a) 0.5Sn-SBA-15; (b) Pt/0.5Sn-SBA-15; (c) Pt/2Sn-SBA-15; (d) Pt/0.5Sn/SBA-15-IM.

ages show that all the samples had well-ordered mesoporous structures, with hexagonally arranged pores, indicating that the samples had the two-dimensional p6mm hexagonal structure [43]. The long-range ordered structure was well maintained without any channel plugging. The simultaneous incorporation of Sn facilitated the distribution of Sn species in the silica framework. The approximate pore size calculated from the TEM images is about $5 \mathrm{~nm}$, which is in good agreement with the $\mathrm{N}_{2}$ adsorption-desorption results. Fig. 8(b), (c), and (d) show that the supports retained well-ordered mesoporous structures after Pt loading, indicating that these materials had high stabilities. No large metal aggregates were observed on the external surface of the support, suggesting high dispersion of the metal particles on the support.

Surface elemental analysis of the catalysts was performed using XPS; the spectra are shown in Fig. 9. Fig. 9(a) shows the Pt $4 f$ XPS profiles. The peaks at 71.3 and $74.6 \mathrm{eV}$ are attributed to $\mathrm{Pt}^{0}$, and that at $78.4 \mathrm{eV}$ arises from $\mathrm{Pt}^{4+}$ species [44]. This indicates that Pt species were present in two forms on the reduced catalysts: metallic and oxidized. The data in Table 2 show that incorporation of an appropriate amount of Sn enhanced interactions between Pt species and the support, and these would help to restrain agglomeration of Pt metal particles. However, the proportion of $\mathrm{Pt}^{4+}$ species decreased with increasing Sn loading, suggesting weaker interactions between Pt species and the support.

The Sn $3 d_{5 / 2}$ XPS profiles are shown in Fig. 9(b). Peak resolution gave three peaks at around 485.6, 486.5, and $487.2 \mathrm{eV}$, which were assigned to different $\mathrm{Sn}$ species. The peak at 485.6 $\mathrm{eV}$ is associated with the reduced $\mathrm{Sn}$ phase, in either the metallic $\left(\mathrm{Sn}^{0}\right)$ or alloyed state [14]. The other two peaks are ascribed to oxidized $\mathrm{Sn}$ species, i.e., $\mathrm{Sn}^{2+}$ and/or $\mathrm{Sn}^{4+}$, which have similar binding energies [45]. The proportions of $\mathrm{Sn}^{0}$ species in Pt/0.5Sn-SBA-15, Pt/2Sn-SBA-15, and Pt/0.5Sn/SBA-15-IM 

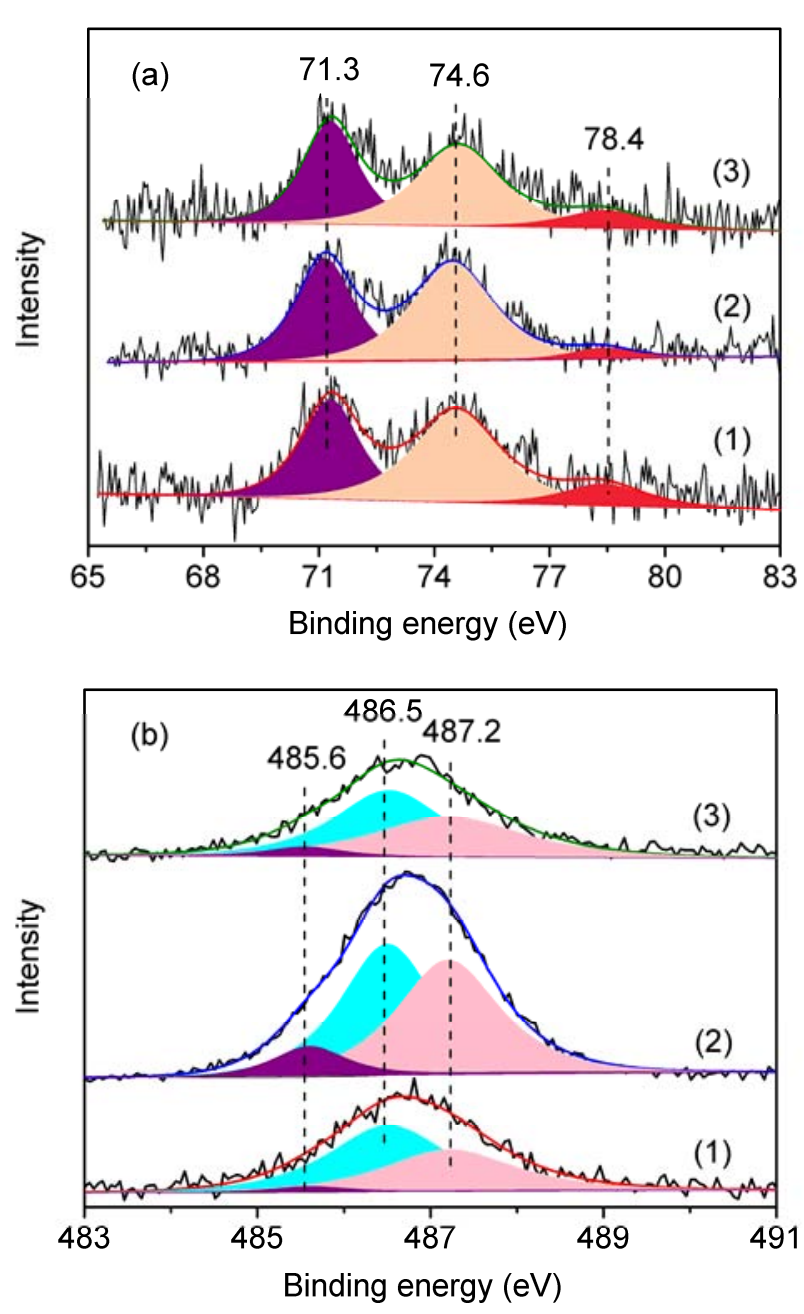

Fig. 9. (a) Pt $4 f$ and (b) Sn $3 d_{5 / 2}$ XPS profiles of reduced catalysts. (1) Pt/0.5Sn-SBA-15; (2) Pt/2Sn-SBA-15; (3) Pt/0.5Sn/SBA-15-IM.

catalyst were $3.1 \%, 8.6 \%$, and $5.2 \%$, respectively (Table 2); most of the Sn species were in the oxidized state. The $\mathrm{Sn}^{2+} / \mathrm{Sn}^{4+}$ stabilities in Pt/0.5Sn-SBA-15 were better than those in the impregnated Pt/0.5Sn/SBA-15-IM sample, showing that the oxidized Sn species were more difficult to reduce in the former case. It can be concluded that the incorporation of a suitable amount of Sn enhanced interactions between Sn species and the support. The mass percentages of surface Pt and Sn showed that the introduction of Sn using the one-pot method gave better dispersion of Pt and Sn species on the catalyst surface than did the post-processing method [46]. However, an incorporation of an excessive amount of Sn weakened the interactions between Sn species and the support, resulting in an increased

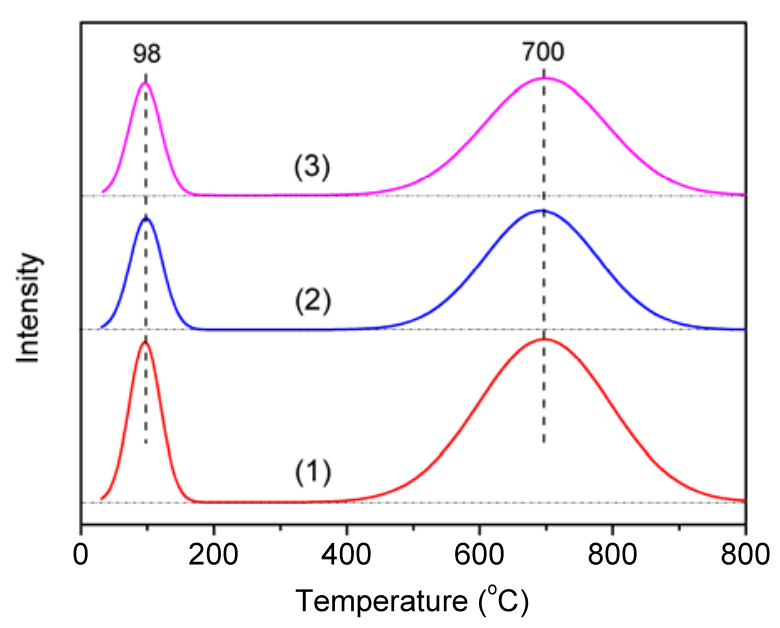

Fig. 10. $\mathrm{H}_{2}$-TPD profiles of catalysts after reduction at $500{ }^{\circ} \mathrm{C}$. (1) Pt/0.5Sn-SBA-15; (2) Pt/2Sn-SBA-15; (3) Pt/0.5Sn/SBA-15-IM.

Table 3

Amounts of $\mathrm{H}_{2}$ desorbed from reduced catalysts.

\begin{tabular}{lccr}
\hline \multirow{2}{*}{ Sample } & \multicolumn{3}{c}{$\mathrm{H}_{2}$ uptake $(\mu \mathrm{L} / \mathrm{g})$} \\
\cline { 2 - 4 } & At $98{ }^{\circ} \mathrm{C}$ & At $700{ }^{\circ} \mathrm{C}$ & Total \\
\hline Pt/0.5Sn-SBA-15 & 20.2 & 95.7 & 115.9 \\
Pt/2Sn-SBA-15 & 16.3 & 56.6 & 72.9 \\
Pt/0.5Sn/SBA-15-IM & 16.7 & 65.1 & 81.8 \\
\hline
\end{tabular}

amount of metallic Sn.

The $\mathrm{H}_{2}$ adsorption capacities of the catalysts were determined using $\mathrm{H}_{2}$-TPD; the profiles are shown in Fig. 10. All the catalysts showed two desorption peaks at different temperatures. The low-temperature desorption peak (98 ${ }^{\circ} \mathrm{C}$ ) was assigned to $\mathrm{H}_{2}$ desorbed from metallic $\mathrm{Pt}$, and the high-temperature $\left(700{ }^{\circ} \mathrm{C}\right)$ desorption peak was attributed to spillover hydrogen [47]. Table 3 shows the amounts of $\mathrm{H}_{2}$ desorbed from the catalysts. The data show that Pt/0.5Sn-SBA-15 gave the largest $\mathrm{H}_{2}$ desorption, especially in the high-temperature range. Metal particle sintering is usually the major cause of decreased $\mathrm{H}_{2}$ adsorption on metallic $\mathrm{Pt}$ [23]. The maximum $\mathrm{H}_{2}$ desorption capacity was achieved by the Pt/0.5Sn-SBA-15 catalyst, indicating that the Pt metal particles were well stabilized, and that the efficiency of the Sn promoter was better than that of the other catalysts. The generation of spillover hydrogen helps to remove coke from the metal sites to the support surface $[48,49]$. However, the total amount of $\mathrm{H}_{2}$ desorbed declined with increasing Sn content, implying that the metallic Pt nature changed significantly. The one-pot synthesis improved the efficiency of the Sn promoter compared with that achieved using the traditional impregnation method.

Table 2

Surface compositions of catalysts obtained using XPS.

\begin{tabular}{|c|c|c|c|c|c|c|}
\hline \multirow{2}{*}{ Sample } & \multicolumn{2}{|c|}{ Pt species (\%) } & \multicolumn{2}{|c|}{ Sn species $(\%)$} & \multirow{2}{*}{$\mathrm{Pt}^{\mathrm{a}}(\mathrm{wt} \%)$} & \multirow{2}{*}{$\mathrm{Sn}^{\mathrm{a}}(\mathrm{wt} \%)$} \\
\hline & $\mathrm{Pt}^{0}$ & $\mathrm{Pt}^{4+}$ & $\mathrm{Sn}^{0}$ & $\mathrm{Sn}^{2+}, \mathrm{Sn}^{4+}$ & & \\
\hline $\mathrm{Pt} / 0.5 \mathrm{Sn}-\mathrm{SBA}-15$ & 90.7 & 9.3 & 3.1 & 96.9 & 0.72 & 0.44 \\
\hline Pt/2Sn-SBA-15 & 96.9 & 3.1 & 8.6 & 91.4 & 0.71 & 1.43 \\
\hline $\mathrm{Pt} / 0.5 \mathrm{Sn} / \mathrm{SBA}-15-\mathrm{IM}$ & 91.5 & 8.5 & 5.2 & 94.8 & 0.65 & 0.39 \\
\hline
\end{tabular}

${ }^{a}$ The mass percent of surface Pt and Sn elemental on the catalysts. 


\subsection{Catalytic performance in propane dehydrogenation and coke analysis}

The propane conversions and propene selectivities as functions of time on stream for the catalysts are shown in Fig. 11. The best catalytic performance, with an optimal initial propane conversion of $43.8 \%$ and propene selectivity of $98.5 \%$, was achieved with the Pt/0.5Sn-SBA-15 sample. Fig. 11(b) shows that the propene selectivities over the catalysts showed similar trends and remained steady during reaction for $6 \mathrm{~h}$. However, the catalyst with a Sn content of $2 \mathrm{wt} \%$ suffered severe deactivation and the propane conversion decreased from $34.4 \%$ to $27.5 \%$ after $6 \mathrm{~h}$ on stream. The catalytic activity and stability of Pt/0.5Sn-SBA-15 were significantly better than those of Pt/0.5Sn/SBA-15-IM because of improved metal dispersion and enhanced interactions among Pt, Sn species, and the support.

Previous discussions suggest that incorporation of an appropriate amount of Sn enhances the interactions among $\mathrm{Pt}, \mathrm{Sn}$, and the support, helping to suppress the agglomeration of $\mathrm{Pt}$ particles and the reduction of Sn species. Under severe reaction conditions, fast sintering of Pt metal particles occurs easily
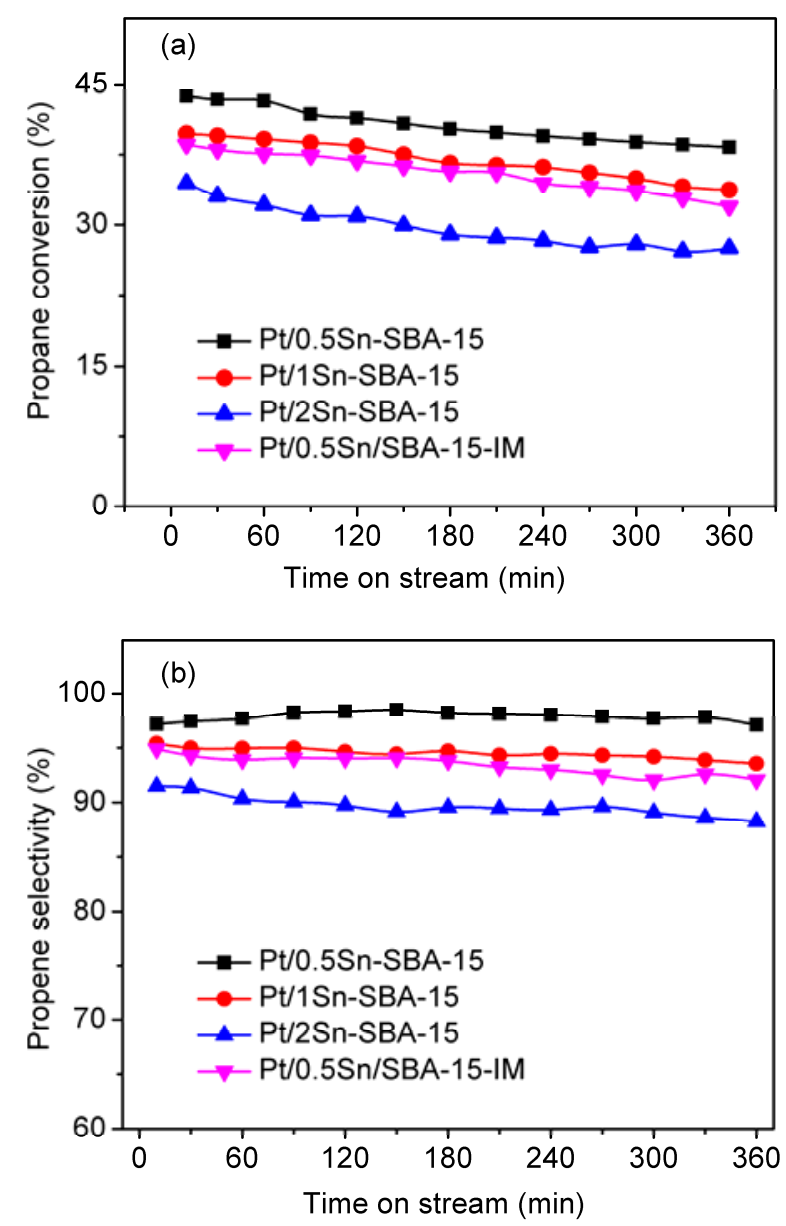

Fig. 11. (a) Propane conversions and (b) propene selectivities as functions of time for various catalysts. Reaction conditions: $580{ }^{\circ} \mathrm{C}$, propane:Ar = 7:3 (molar ratio), $0.1 \mathrm{MPa}, \mathrm{WHSV}=8.25 \mathrm{~h}^{-1}$, catalyst mass 0.2 g. when interactions between Pt species and the support are weak. This causes rapid hydrogenolysis and a decline in the propene selectivity because this undesired side reaction relies on the presence of large Pt clusters [50]. It has also been proposed that on the surface of a PtSn catalyst, the Pt active sites are present in two forms: $\mathrm{M}_{1}$ and $\mathrm{M}_{2}$ sites. $\mathrm{M}_{1}$ sites are multiple $\mathrm{Pt}$ centers generated from Pt directly loaded on the support surface, and Pt particles anchored on the $\mathrm{SnO}_{x}$ surfaces in sandwich structures correspond to $\mathrm{M}_{2}$ sites [51]. Generally, $\mathrm{M}_{1}$ sites are responsible for side reactions such as hydrogenolysis and coking, and $\mathrm{M}_{2}$ sites are the main active sites for propane dehydrogenation [51]. Enhanced interactions between Sn species and the support suppress the reduction of Sn species and stabilize the oxidation states of $\mathrm{Sn}$, and this encourages the development of $M_{2}$ sites. In this case, more stable $M_{2}$ active sites are present in the Sn-incorporated catalyst and a better catalytic performance is obtained.

Table 4 shows the deactivation parameters for the catalysts after reaction for $6 \mathrm{~h}$. Introduction of an excessive amount of Sn decreased the catalyst stability. The stabilities of the catalysts decreased in the order Pt/0.5Sn-SBA-15 > Pt/1Sn-SBA-15 > Pt/0.5Sn/SBA-15-IM > Pt/2Sn-SBA-15.

The changes in the surface morphologies of the catalysts after the catalytic performance tests were investigated using TEM. Fig. 12 shows that all the samples retained a well-ordered mesoporous structure even after reaction for $6 \mathrm{~h}$. Coke species were found on the surfaces of the spent Pt/2Sn-SBA-15 and $\mathrm{Pt} / 0.5 \mathrm{Sn} / \mathrm{SBA}-15-\mathrm{IM}$ catalysts. No coke species were observed on the spent Pt/0.5Sn-SBA-15 sample, indicating a high anti-coking ability. The metal particles in the spent Pt/0.5Sn-SBA-15 sample were confined in the channels (Fig. 12(a)). Confinement by the mesoporous structure helped to stabilize the metal particles, which enhanced the catalyst stability during propane dehydrogenation [52].

Coke deposition is a major cause of catalyst deactivation during propane dehydrogenation. TGA was used to identify and quantify carbon deposits on the spent catalysts. Fig. 13 shows that there were two successive mass loss regions for the spent catalysts, representing two types of coke deposit. In general, coke precursors are initially generated from the external surfaces of the active metal and then moved to the support, followed by dehydrogenation and condensation [52]. The first mass loss, at $150-400{ }^{\circ} \mathrm{C}$, is assigned to coke located on the metal surfaces, and the high-temperature mass loss (400-750 ${ }^{\circ} \mathrm{C}$ ) corresponds to coke deposited on the support [23]. The combustion temperature for coke deposited on the metal sur-

Table 4

Initial conversions $\left(X_{0}\right)$, final conversions $\left(X_{\mathrm{f}}\right)$, deactivation parameters $(D)$, and coke contents after reaction for $6 \mathrm{~h}$ at $580^{\circ} \mathrm{C}$ over various catalysts.

\begin{tabular}{lcccc}
\hline Catalyst & $X_{0}(\%)$ & $X_{\mathrm{f}}(\%)$ & $D^{\mathrm{a}}$ & Coke amount $(\mathrm{wt} \%)$ \\
\hline Pt/0.5Sn-SBA-15 & 43.8 & 38.3 & 12.6 & 6.65 \\
Pt/1Sn-SBA-15 & 39.8 & 33.7 & 15.3 & 6.93 \\
Pt/2Sn-SBA-15 & 34.4 & 27.5 & 20.0 & 11.39 \\
Pt/0.5Sn/SBA-15-IM & 39.6 & 32.0 & 19.2 & 11.13 \\
${ }^{\mathrm{a}} D=100 \times\left(X_{0}-X_{\mathrm{f}}\right) / X_{0}$. & & & &
\end{tabular}




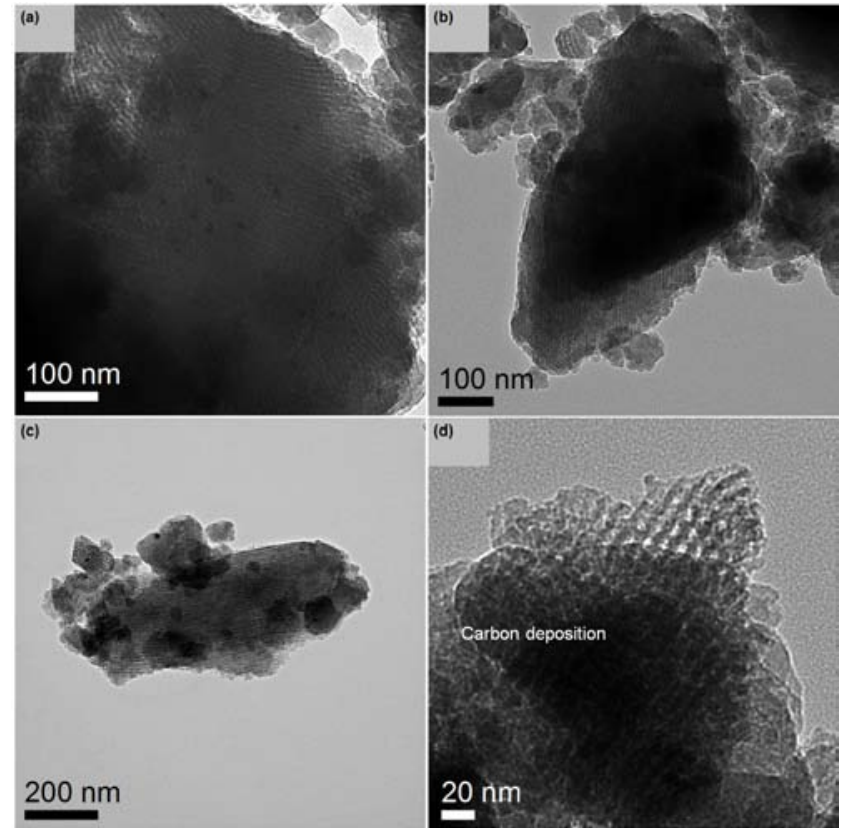

Fig. 12. TEM images of spent catalysts. (a) Pt/0.5Sn-SBA-15; (b) Pt/2Sn-SBA-15; (c, d) Pt/0.5Sn/SBA-15-IM.

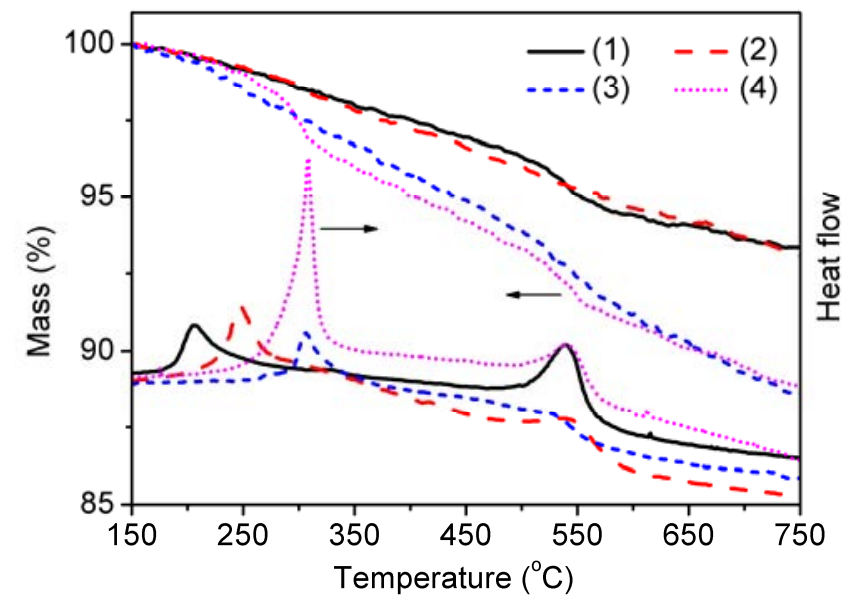

Fig. 13. TG-DTA profiles of spent catalysts. (1) Pt/0.5Sn-SBA-15; (2) Pt/1Sn-SBA-15; (3) Pt/2Sn-SBA-15; (4) Pt/0.5Sn/SBA-15-IM.

faces of Pt/0.5Sn-SBA-15 was lower than those for coke deposits on the other catalysts. This suggests that incorporation of an appropriate amount of $\mathrm{Sn}$ increased activation of coke on the metal sites. The amounts of coke deposited followed the order Pt/0.5Sn-SBA-15 (6.6\%) < Pt/1Sn-SBA-15 (6.9\%) < Pt/0.5Sn/SBA-15-IM (11.2\%) < Pt/2Sn-SBA-15 (11.4\%). The coke analysis results are in accordance with the $\mathrm{H}_{2}$-TPD and XPS results.

\section{Conclusions}

Sn-incorporated SBA-15 mesoporous materials with high specific surface areas were prepared by one-pot hydrothermal synthesis. The catalytic performances of these catalysts were compared with that of a catalyst prepared using a conventional impregnation method. The results show that incorporation of Sn species produced strong interactions between Sn species and the support, resulting in large amounts of $\mathrm{Sn}$ in a stable oxidized form. The introduction of Sn using the one-pot method also improved the promotion efficiency of Sn compared with that of Sn in the impregnated sample. An excessive amount of Sn weakened the interactions among Pt species, Sn species, and the support, resulting in a decrease in the catalytic activity. The Pt catalysts supported on Sn-incorporated SBA-15 showed excellent catalytic activities and stabilities in propane dehydrogenation. The Pt/0.5Sn-SBA-15 sample showed the best propene selectivity, i.e., $98.5 \%$, with a corresponding propane conversion of about $43.8 \%$, and the lowest deactivation parameter $(12.6 \%)$ after reaction for $6 \mathrm{~h}$.

\section{References}

[1] S. Sokolov, M. Stoyanova, U. Rodemerck, D. Linke, E. V. Kondratenko, Catal. Sci. Technol., 2014, 4, 1323-1332.

[2] Z. H. Ma, J. Wang, J. Li, N. N. Wang, C. H. An, L. Y. Sun, Fuel Process. Technol, 2014, 128, 283-288.

[3] L. N. Li, W. L. Zhu, L. Shi, Y. Liu, H. C. Liu, Y. M. Ni, S. P. Liu, H. Zhou, Z. M. Liu, Chin. J. Catal., 2016, 37, 359-366.

[4] M. S. Kumar, D. Chen, J. C. Walmsley, A. Holmen, Catal. Commun., 2008, 9, 747-750.

[5] L. H. Huang, B. L. Xu, L. L. Yang, Y. N. Fan, Catal. Commun., 2008, 9 , 2593-2597.

[6] G. Liu, L. Zeng, Z. J. Zhao, H. Tian, T. F. Wu, J. L. Gong, ACS Catal., 2016, 6, 2158-2162.

[7] Z. P. Han, S. R. Li, F. Jiang, T. Wang, X. B. Ma, J. L. Gong, Nanoscale, 2014, 6, 10000-10008.

[8] E. Gbenedio, Z. T. Wu, I. Hatim, B. F. K. Kingsbury, K. Li, Catal. Today, 2010, 156, 93-99.

[9] B. K. Vu, M. B. Song, I. Y. Ahn, Y. W. Suh, D. J. Suh, W. I. Kim, H. L. Koh, Y. G. Choi, E. W. Shin, Appl. Catal. A, 2011, 400, 25-33.

[10] T. Shishido, K. Shimamura, K. Teramura, T. Tanaka, Catal. Today, 2012, 185, 151-156.

[11] X. F. Gao, C. L. Chen, S. Y. Ren, J. Zhang, D. S. Su, Chin. J. Catal., 2012, 33, 1069-1074.

[12] G. Siddiqi, P. P. Sun, V. Galvita, A. T. Bell, J. Catal, 2010, 274, 200-206.

[13] Y. W. Zhang, Y. M. Zhou, A. D. Qiu, Y. Wang, Y. Xu, P. C. Wu, Catal. Commun., 2006, 7, 860-866.

[14] Y. W. Zhang, M. W. Xue, Y. M. Zhou, H. X. Zhang, W. Wang, Q. L. Wang, X. L. Sheng, RSC Adv., 2016, 6, 29410-29422.

[15] L. D. Deng, T. Shishido, K. Teramura, T. Tanaka, Catal. Today, 2014, 232, 33-39.

[16] L. L. Long, W. Z. Lang, X. Yan, K. Xia, Y. J. Guo, Fuel Process. Technol., 2016, 146, 48-55.

[17] M. L. Yang, Y. A. Zhu, X. G. Zhou, Z. J. Sui, D. Chen, ACS Catal., 2012, 2,1247-1258.

[18] M. S. Kumar, D. Chen, A. Holmen, J. C. Walmsley, Catal. Today, 2009, 142, 17-23.

[19] R. Burch, J. Catal., 1981, 71, 348-359.

[20] W. S. Yang, L. W. Lin, Y. N. Fan, J. L. Zang, Catal. Lett., 1992, 12, 267-276.

[21] M. S. Kumar, A. Holmen, D. Chen, Microporous Mesoporous Mater., 2009, 126, 152-158.

[22] B. K. Vu, E. W. Shin, I. Y. Ahn, J. M. Ha, D. J. Suh, W. I. Kim, H. L. Koh, 


\section{Graphical Abstract}

Chin. J. Catal., 2017, 38: 726-735 doi: 10.1016/S1872-2067(17)62805-5

Ordered mesoporous Sn-SBA-15 as support for Pt catalyst with enhanced performance in propane dehydrogenation

Bing Li, Zhenxin Xu, Wei Chu, Shizhong Luo *, Fangli Jing * Sichuan University, China; Université de Strasbourg, France

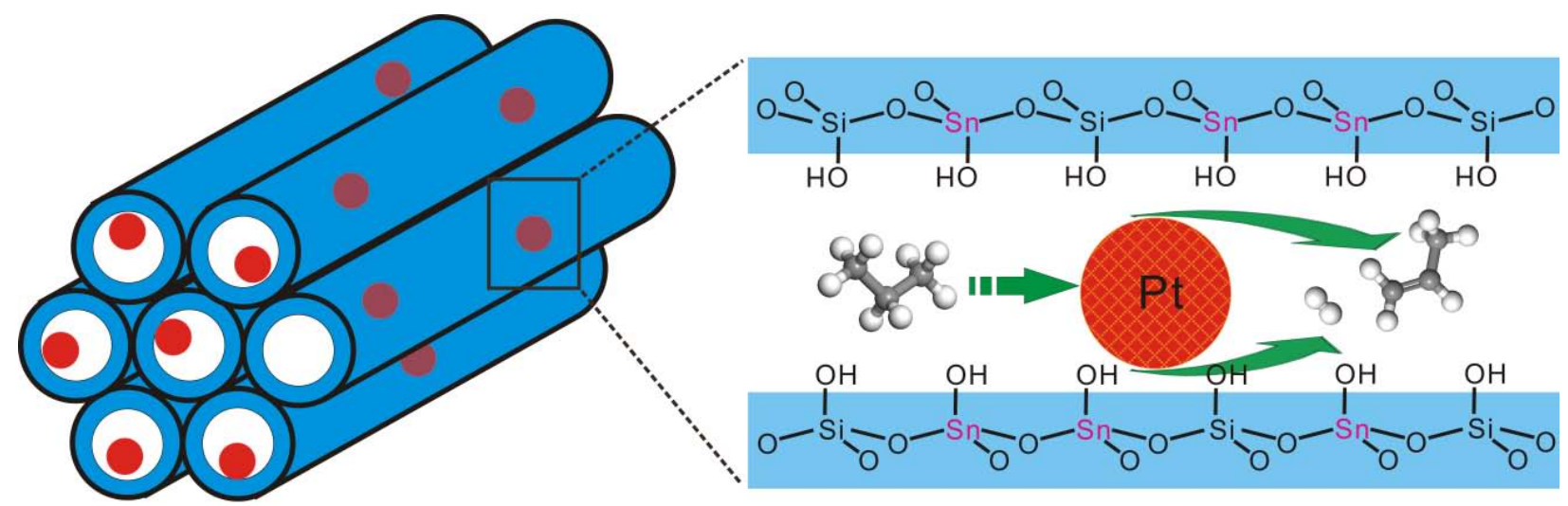

\section{$\mathrm{Pt} / \mathrm{Sn}-\mathrm{SBA}-15$}

A facile one-pot method was used to synthesize ordered mesoporous Sn-SBA-15-supported Pt catalysts with stable $\mathrm{SnO}_{x}$ species and enhanced promotion by Sn species. The materials gave excellent catalytic performance and good resistance to coking in propane dehydrogenation.

Y. G. Choi, S. B. Lee, Catal. Lett., 2012, 142, 838-844.

[23] Y. W. Zhang, Y. M. Zhou, J. J. Shi, S. J. Zhou, X. L. Sheng, Z. W. Zhang, S. M. Xiang, J. Mol. Catal. A, 2014, 381, 138-147.

[24] O. A. Barias, A. Holmen, E. A. Blekkan, J. Catal., 1996, 158, 1-12.

[25] P. Shah, A. V. Ramaswamy, K. Lazar, V. Ramaswamy, Microporous Mesoporous Mater., 2007, 100, 210-226.

[26] N. Wang, W. Chu, T. Zhang, X. S. Zhao, Int. J. Hydrogen Energy, 2012, 37, 19-30.

[27] B. Li, Z. X. Xu, F. L. Jing, S. Z. Luo, N. Wang, W. Chu, J. Energy Chem., 2016, 25, 1078-1085.

[28] M. Impéror-Clerc, P. Davidson, A. Davidson, J. Am. Chem. Soc., 2000, 122, 11925-11933.

[29] N. Wang, X. P. Yu, K. Shen, W. Chu, W. Z. Qian, Int. J. Hydrogen Energy, 2013, 38, 9718-9731.

[30] P. M. Rao, A. Wolfson, S. Kababya, S. Vega, M. V. Landau, J. Catal., 2005, 232, 210-225.

[31] B. Li, Z. X. Xu, F. L. Jing, S. Z. Luo, W. Chu, Appl. Catal. A, 2017, 533, 17-27.

[32] Y. Kitayama, H. Asano, T. Kodama, J. Abe, Y. Tsuchiya, J. Porous Mater., 1998, 5, 139-146.

[33] V. Ramaswamy, P. Shah, K. Lazar, A. V. Ramaswamy, Catal. Surv. Asia, 2008, 12, 283-309.

[34] M. Sasidharan, Y. Kiyozumi, N. K. Mal, M. Paul, P. R. Rajamohanan, A. Bhaumik, Microporous Mesoporous Mater., 2009, 126, 234-244.

[35] M. Selvaraj, S. Kawi, J. Mater. Chem., 2007, 17, 3610-3621.

[36] G. Engelhardt, R. Radeglia, Chem. Phys. Lett., 1984, 108, 271-274.

[37] G. Luo, S. R. Yan, M. H. Qiao, K. N. Fan, Appl. Catal. A, 2007, 332, 79-88.
[38] N. Chino, T. Okubo, Microporous Mesoporous Mater., 2005, 87, 15-22.

[39] C. Y. Peng, H. J. Zhang, J. B. Yu, Q. G. Meng, L. S. Fu, H. R. Li, L. N. Sun, X. M. Guo, J. Phys. Chem. B., 2005, 109, 15278-15287.

[40] D. Y. Zhao, J. L. Feng, Q. S. Huo, N. Melosh, G. H. Frederickson, B. F. Chmelka, G. D. Stucky, Science, 1998, 279, 548-552.

[41] X. Q. Fan, J. M. Li, Z. Zhao, Y. C. Wei, J. Liu, A. J. Duan, G. Y. Jiang, Catal. Sci. Technol., 2015, 5, 339-350.

[42] J. Yang, K. Hidajat, S. Kawi, Mater. Lett., 2008, 62, 1441-1443.

[43] P. Shah, A. V. Ramaswamy, K. Lazar, V. Ramaswamy, Appl. Catal. A, 2004, 273, 239-248.

[44] L. K. Ono, J. R. Croy, H. Heinrich, B. R. Cuenya, J. Phys. Chem. C, 2011, 115, 16856-16866.

[45] Y. W. Zhang, Y. M. Zhou, J. J. Shi, S. J. Zhou, Z. W. Zhang, S. C. Zhang, M. P. Guo, Fuel Process. Technol., 2013, 111, 94-104.

[46] Z. X. Xu, N. Wang, W. Chu, J. Deng, S. Z. Luo, Catal. Sci. Technol., 2015, 5, 1588-1597.

[47] S. B. He, C. L. Sun, Z. W. Bai, X. H. Dai, B. Wang, Appl. Catal. A, 2009, 356, 88-98.

[48] Y. W. Zhang, Y. M. Zhou, M. H. Tang, X. Liu, Y. Z. Duan, Chem. Eng. J., 2012, 181-182, 530-537.

[49] L. W. Lin, T. Zhang, J. L. Zang, Z. S. Xu, Appl. Catal., 1990, 67, 11-23.

[50] R. D. Cortright, J. A. Dumesic, J. Catal., 1994, 148, 771-778.

[51] Y. W. Zhang, Y. M. Zhou, L. H. Wan, M. W. Xue, Y. J. Duan, X. Liu, Fuel Process. Technol., 2011, 92, 1632-1638.

[52] X. Q. Fan, J. M. Li, Z. Zhao, Y. C. Wei, J. Liu, A. J. Duan, G. Y. Jiang, RSC $A d v ., 2015,5,28305-28315$. 


\title{
有序介孔Sn-SBA-15负载铂催化剂上丙烷脱氢性能的提高
}

\author{
李 冰 $^{\mathrm{a}}$ ，徐振新 ${ }^{\mathrm{b}}$ ，储 伟 ${ }^{\mathrm{a}}$ ，罗仕忠 ${ }^{\mathrm{a},{ }^{*}}$, 敬方梨 ${ }^{\mathrm{a}, \#}$ \\ a四川大学化学工程学院, 四川成都610065 \\ b斯特拉斯堡大学能源、环境与健康化学过程研究所, 斯特拉斯堡市, 法国
}

\begin{abstract}
摘要: 丙烷脱氢制丙烯能够将低级烷烃转变成烯烃, 是有效扩大丙烯来源的生产工艺. 铂锡催化剂用于丙烷催化脱氢的主 要缺点是稳定性差、选择性低, 通过稳定锡的氧化态可以大大改善催化剂的脱氢性能及稳定性. 本文采用一锅水热合成法 制备了一系列高比表面积具有高度有序介孔结构的Sn掺杂的Sn-SBA-15材料, 并作为载体负载铂催化剂用于丙烷脱氢反 应. 同时利用传统浸渍法(IM)合成了Sn/SBA-15-IM材料作为对比. 结合X射线衍射(XRD)、BET比表面积和孔体积测试、 红外光谱(FT-IR)、X射线光电子能谱、 $\mathrm{H}_{2}$ 程序升温脱附 $\left(\mathrm{H}_{2}-\mathrm{TPD}\right)$ 、热重分析(TGA)、扫描电镜和透射电镜等多种物理化学 表征手段研究了Sn-SBA-15材料和催化剂的结构性质及其丙烷脱氢反应性能. XRD和BET比表面积和孔体积测试结果表 明, 水热合成法原位引入助剂Sn不影响载体SBA-15的有序孔道结构, 同时能够保持较大的比表面积. 传统浸渍法引入Sn会 堵塞载体孔道, 载体比表面积及孔道有序度下降. Sn掺杂进入SBA-15骨架能够增强Sn物种与载体的相互作用, 有利于 $S n$ 物 种在反应过程中保持氧化态, 提高催化剂丙烷脱氢反应的活性及选择性. 当 Sn掺杂量增至 $2.0 \mathrm{wt} \%$ 时, Pt, Sn组分与载体之 间的相互作用减弱, 催化剂中 $\mathrm{Sn}^{0}$ 物种所占比例增多, 导致催化剂丙烷脱氢性能下降. 在丙烷脱氢反应过程中, 一锅法引入 $\mathrm{Sn}$ 的催化剂上反应活性和稳定性明显优于浸渍法引入 $\mathrm{Sn}$ 的催化剂. 其中, Pt/0.5Sn-SBA-15催化剂表现出最优的丙烷脱氢 性能, 丙烷转化率为 $43.8 \%$, 丙烯选择性为 $98.5 \%$.
\end{abstract}

关键词: 丙烷脱氢; 一锅水热合成; Sn掺杂SBA-15; 铂基催化剂; 构效关系

收稿日期: 2017-01-11. 接受日期: 2017-03-03. 出版日期: 2017-04-05.

*通讯联系人. 电话: (028)85403836; 传真: (028)85461108; 电子信箱: luosz@scu.edu.cn

\#通讯联系人. 电话: (028)85403836; 传真: (028)85461108; 电子信箱: fangli.jing@scu.edu.cn

基金来源：四川省科技支撑计划 (2016GZ0371); 国家自然科学基金(21476145, 21506111).

本文的英文电子版由Elsevier出版社在ScienceDirect上出版(http://www.sciencedirect.com/science/journal/18722067). 